\title{
Immunogenetic studies in families with rheumatoid arthritis and autoimmune thyroid disease
}

\author{
PAUL A SANDERS*, DAVID M GRENNAN*, PHILIP A DYER†, \\ GERDA G DE LANGE $\ddagger$, AND RODNEY HARRIS † \\ From *the University of Manchester Rheumatic Diseases Centre, Hope Hospital, Salford; the Tissue \\ Typing Laboratory, Department of Medical Genetics, St Mary’s Hospital, Manchester; and ¥the Central \\ Laboratory of the Netherlands Red Cross Blood Transfusion Service, Amsterdam.
}

SUMmARY HLA and Gm typing were carried out in 16 families. Seven families included 10 sib pairs with rheumatoid arthritis (RA) and autoimmune thyroid disease (ATD) respectively, and nine families included 16 sib pairs with RA and circulating thyroid autoantibodies respectively. Eight, 11, and seven sib pairs with either RA or clinical or immunological evidence of ATD shared none, one, and two HLA haplotypes respectively, and two, seven, and two informative sib pairs shared none, one, and two $\mathrm{Gm}$ haplotypes respectively. This random haplotype sharing of HLA and Gm haplotypes suggests that non-HLA, non-Gm linked genes are likely to be involved in any genetic predisposition common to RA and ATD.

The observation that autoimmune thyroid disorders (ATD) occur more frequently than expected in first and second degree relatives of probands with rheumatoid arthritis (RA) suggests that these diseases may have susceptibility gene(s) in common. ${ }^{1}$ There is a well documented association in most Caucasian populations between RA and HLADR4. ${ }^{2}$ In Caucasians, Graves' disease is associated with HLA-DR $3^{3}$ and Hashimoto's disease with HLA-DR5. ${ }^{4}$ Immunoglobulin heavy chain genes (Gm) map to chromosome $14^{5}$ and there is an association between the $\mathrm{G} 1 \mathrm{~m}(\mathrm{x})$ allotype and DR4 positive RA, ${ }^{6}{ }^{7}$ and between the $\mathrm{Gm}$ fnb phenotype and Graves' disease. ${ }^{8}$ We have previously suggested that genes for ATD, either linked or non-linked to HLA, can predispose to RA independently of the susceptibility gene in linkage disequilibrium with HLA-DR4. ${ }^{9}$ If the increased familial aggregation of RA and ATD is produced by HLA or Gm linked genes in common, then HLA or Gm haplotype sharing by sib pairs with RA and ATD respectively should be greater than random. In the present study we have examined this possibility by HLA and Gm typing members of 16 families which include sib pairs with RA and either clinical or immunological evidence of ATD, respectively.

Received for publication 2 May 1985. Accepted for publication 15 July 1985.

\section{Patients and methods}

FAMILIES

Fifty-eight Caucasian families which include either two or more first degree relatives with RA or sibs with RA and autoimmune thyroid disease alone respectively have been investigated. The probands of all families live in Greater Manchester and were ascertained through probands attending rheumatology or endocrinology (one family) clinics as well as through local branches of Arthritis Care. In seven of these families there are $10 \mathrm{sib}$ pairs in which one member has RA alone and the other autoimmune thyroid disease alone. In nine further families, there are 16 sib pairs in which the proband has RA and the sib circulating thyroid autoantibodies without clinical evidence of ATD.

Patients were categorised as having RA if they satisfied the criteria of the American Rheumatism Association for classical or definite disease. ${ }^{10}$ ATD included (1) a definite history of Graves' disease (excluding multinodular goitre), (2) primary hypothyroidism with circulating thyroid autoantibodies, or (3) Hashimoto's disease.

\section{LABORATORY STUDIES}

HLA-A and $B$ antigens were defined by the standard NIH technique. HLA-DR antigens were defined using B lymphocytes isolated from peripheral blood by their adherence to nylon wool 
columns. All antisera were obtained locally or through mutual exchanges and were characterised using a cell panel typed with 9th International Histocompatibility antisera.

The following immunoglobulin allotypes were detected by haemagglutination inhibition assay of serum $^{11}$ : G1m, (z,a,x,f), G2m(n), G3m (g, b0, b1, b3, b5, s, t, c3, c5), A m $(1,2)$. G3m (b0, b1, b3, and b5) normally occur together and are summarised as G3m(b). Gm allotypes follow co-dominant inheritance in groups or haplotypes and there are four common $\mathrm{Gm}$ haplotypes in Caucasians: $\mathrm{fnb}, \mathrm{fb}$, zaxg, and zag.

Sera from family members were tested for the following autoantibodies: rheumatoid factor (sheep cell agglutination test using the RAHA kit, Fujizoki Pharmaceuticals), antinuclear antibody (using rat liver substrate and fluorescein conjugated sheep antihuman immunoglobulin), antithyroglobulin antibodies (Thymune-T, Wellcome), and antithyr- oid microsomal antibodies (Thymune-M, Wellcome). The following titres were considered positive for each test on the basis of previous population studies $^{12}$ : rheumatoid factor $1: 32$, ANF $1: 40$, antithyroid thyroglobulin $1: 40$, and antithyroid microsomal $1: 1600$.

\section{ANALYSIS}

If HLA or Gm haplotypes are inherited at random in a sibship, the probabilities of any sib sharing none, one, or two haplotypes with the proband are $0.25,0.5$, and 0.25 , respectively.

\section{Results}

The clinical details of the seven families are summarised in table 1 . Pedigrees and results of HLA typing and $\mathrm{Gm}$ allotyping are shown in figs 1 to 7 .

In family 1 there are two sisters, one of whom has of RA (II.2) and the other Hashimoto's disease (II.1). They share neither HLA nor Gm haplotypes.

TABLE 1 Clinical and laboratory details of families.

\begin{tabular}{|c|c|c|c|c|c|c|c|}
\hline Family & & Patient & Disease & $S C A T$ & Anti-TG & Anti-TM & Treatment \\
\hline 1 & $\begin{array}{l}\text { I.1 } \\
\text { I. } \\
\text { II } .1 \\
\text { II } .2\end{array}$ & $\begin{array}{l}\text { Proband } \\
\text { Sister } \\
\text { Daughter } \\
\text { Daughter }\end{array}$ & $\begin{array}{l}\text { RA } \\
\text { PA } \\
\text { Hash } \\
\text { RA }\end{array}$ & $\begin{array}{l}\text { Negative } \\
\text { Negative } \\
\text { Negative } \\
\text { Negative }\end{array}$ & $\begin{array}{l}1: 640 \\
1: 640 \\
\text { Negative } \\
\text { Negative }\end{array}$ & $\begin{array}{l}\text { Negative } \\
1: 25600 \\
1: 26000000 \\
\text { Negative }\end{array}$ & $\begin{array}{l}\text { NSAID } \\
\text { B12 } \\
\text { NSAID }\end{array}$ \\
\hline 2 & \begin{tabular}{l|} 
I.1 \\
I.2 \\
I. 3 \\
II. 1 \\
II. \\
II. 4
\end{tabular} & $\begin{array}{l}\text { Father } \\
\text { Aunt } \\
\text { Aunt } \\
\text { Brother } \\
\text { Proband } \\
\text { Brother }\end{array}$ & $\begin{array}{l}\text { RA } \\
\text { Graves' } \\
\text { RA }\end{array}$ & $\begin{array}{l}1: 512 \\
\text { Negative } \\
1: 64 \\
\text { Negative } \\
\text { Negative } \\
\text { Negative }\end{array}$ & $\begin{array}{l}\text { Negative } \\
\text { Negative } \\
1: 80 \\
\text { Negative } \\
\text { Negative } \\
\text { Negative }\end{array}$ & $\begin{array}{l}\text { Negative } \\
\text { Negative } \\
1: 6400 \\
\text { Negative } \\
\text { Negative } \\
\text { Negative }\end{array}$ & $\begin{array}{l}\text { NSAID } \\
\text { Surgery } \\
\text { Chloroquine }\end{array}$ \\
\hline 3 & $\begin{array}{l}\text { I.2 } \\
\text { I. } 3 \\
\text { I.4 } \\
\text { II. } 1\end{array}$ & $\begin{array}{l}\text { Proband } \\
\text { Sister } \\
\text { Brother } \\
\text { Son }\end{array}$ & $\begin{array}{l}\text { RA } \\
\text { Graves' } \\
\text { RA }\end{array}$ & $\begin{array}{l}1: 4096 \\
\text { Negative } \\
1: 256 \\
\text { Negative }\end{array}$ & $\begin{array}{l}\text { Negative } \\
1: 160 \\
\text { Negative } \\
\text { Negative }\end{array}$ & $\begin{array}{l}\text { Negative } \\
\text { 1:409 } 600 \\
\text { Negative } \\
\text { Negative }\end{array}$ & $\begin{array}{l}\text { Gold } \\
\text { Carbimazole } \\
\text { NSAID }\end{array}$ \\
\hline 4 & \begin{tabular}{l|} 
I.2 \\
II. 1 \\
II. 2 \\
II. 3
\end{tabular} & $\begin{array}{l}\text { Mother } \\
\text { Sister } \\
\text { Proband } \\
\text { Sister }\end{array}$ & $\begin{array}{l}\text { Hypothyroid } \\
\text { RA } \\
\text { RA }\end{array}$ & $\begin{array}{l}\text { Negative } \\
\text { Negative } \\
1: 512 \\
1: 32\end{array}$ & $\begin{array}{l}\text { Negative } \\
\text { Negative } \\
\text { Negative } \\
\text { Negative }\end{array}$ & $\begin{array}{l}\text { Negative } \\
1: 1638400 \\
\text { Negative } \\
\text { Negative }\end{array}$ & $\begin{array}{l}\text { Thyroxine } \\
\text { Gold, penicillamine, } \\
\text { ACTH, chloroquirie } \\
\text { Chloroquine }\end{array}$ \\
\hline 5 & $\begin{array}{l}\text { I. } 1 \\
\text { I. } \\
\text { I. } \\
\\
\text { I.4 } \\
\text { I. } \\
\end{array}$ & $\begin{array}{l}\begin{array}{l}\text { Sister } \\
\text { Brother } \\
\text { Proband }\end{array} \\
\text { Sister } \\
\text { Half-sister }\end{array}$ & $\begin{array}{l}\text { Graves' } \\
\text { RA } \\
\text { RA. Felty’s }\end{array}$ & $\begin{array}{l}\text { Negative } \\
1: 64 \\
1: 4096 \\
\\
\text { Negative } \\
\text { Negative }\end{array}$ & $\begin{array}{l}\text { Negative } \\
\text { Negative } \\
\text { Negative } \\
\\
\text { Negative } \\
\text { Negative }\end{array}$ & $\begin{array}{l}\text { 1:1600 } \\
\text { Negative } \\
\text { Negative } \\
\text { Negative } \\
\text { Negative }\end{array}$ & $\begin{array}{l}131_{1} \\
\text { Chloroquine } \\
\text { Gold, chloroquine, } \\
\text { prednisolone }\end{array}$ \\
\hline 6 & \begin{tabular}{l|} 
I. \\
I.2 \\
II.1 \\
II. \\
\\
II. \\
II. \\
II. \\
II. \\
I.
\end{tabular} & $\begin{array}{l}\text { Father } \\
\text { Mother } \\
\text { Sister } \\
\text { Proband } \\
\text { Brother } \\
\text { Sister } \\
\text { Brother }\end{array}$ & $\begin{array}{l}\text { Graves' } \\
\text { RA }\end{array}$ & $\begin{array}{l}\text { Negative } \\
\text { Negative } \\
\text { Negative } \\
1: 32 \\
\text { Negative } \\
\text { Negative } \\
\text { Negative }\end{array}$ & $\begin{array}{l}\text { Negative } \\
\text { Negative } \\
1: 40 \\
\text { Negative } \\
\\
\text { Negative } \\
\text { Negative } \\
\text { Negative }\end{array}$ & $\begin{array}{l}\text { Negative } \\
\text { Negative } \\
1: 6000000 \\
\text { Negative } \\
\text { Negative } \\
1: 6400 \\
\text { Negative }\end{array}$ & $\begin{array}{l}\text { Carbimazole } \\
\text { Penicillamine, gold, } \\
\text { chloroquine }\end{array}$ \\
\hline 7 & $\begin{array}{l}I .3 \\
I .4\end{array}$ & $\begin{array}{l}\text { Brother } \\
\text { Proband }\end{array}$ & $\begin{array}{l}\text { RA } \\
\text { Hypothyroid }\end{array}$ & $\begin{array}{l}\text { 1:64 } \\
\text { Negative }\end{array}$ & $\begin{array}{l}\text { Negative } \\
\text { Negative }\end{array}$ & $\begin{array}{l}\text { Negative } \\
1: 1600\end{array}$ & $\begin{array}{l}\text { Chloriquine, gold } \\
\text { Thyroxine }\end{array}$ \\
\hline
\end{tabular}

$\mathrm{PA}=$ pernicious anaemia.

Hash = Hashimoto's thyroiditis.

Anti-TG=antithyroid globulin antibody.

Anti-TM=antithyroid microsomal antibody. 
Immunogenetic studies in families with rheumatoid arthritis and autoimmune thyroid disease

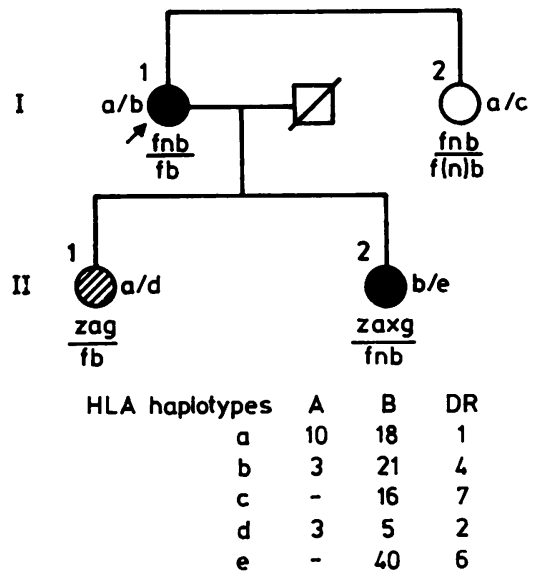

FIG 1 Family 1. $=R A,=A T D$. The Gm haplotypes are shown beneath each family member.

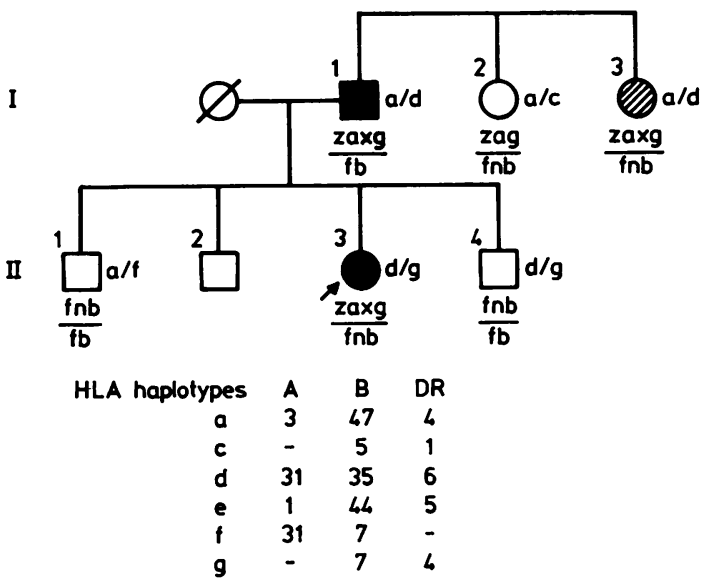

FIG 2 Family 2.
I

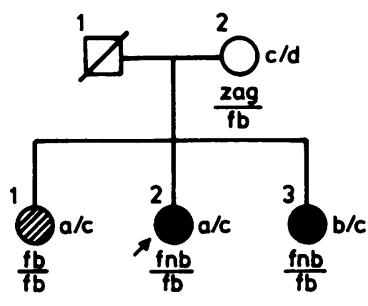

HLA haplotypes A B DR

$\begin{array}{cccc}\text { ypes } & A & B & D R \\ \text { a } & 2 & 16 & 1 \\ \text { b } & 3 & 5 & 5 \\ \text { c } & 30 & 8 & 3 \\ \text { d } & 2 & 46 & 4\end{array}$

FIG 4 Family 4.

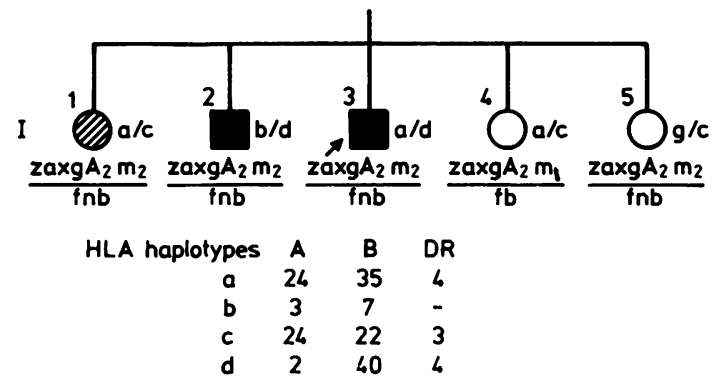

FIG 5 Family 5. 1.5 is a half-sister. The A2m allotype is informative in distinguishing the zaxg haplotypes.
I

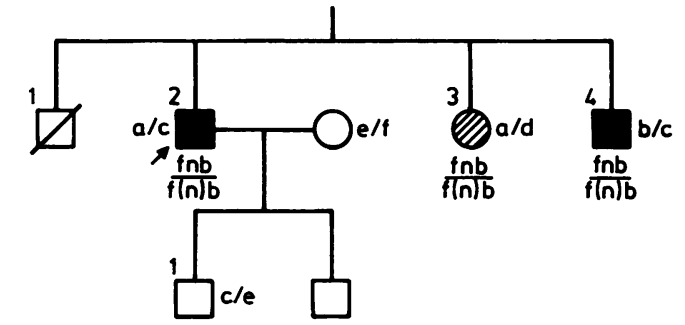

HLA haplotypes A B DR

$\begin{array}{cccc}\text { a } & 30 & 40 & 5 \\ \text { b } & 3 & 40 & 7 \\ \text { c } & 32 & 7 & 5 \\ \text { d } & 3 & 46 & - \\ \text { e } & 2 & - & 2\end{array}$

FIG 3 Family 3. 


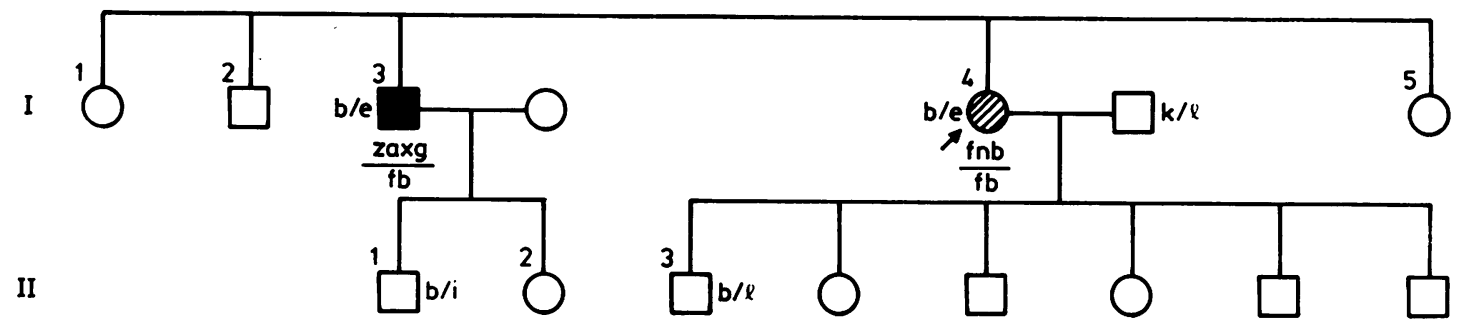

$\begin{array}{cccc}\text { HLA haplotypes } & \text { A } & \text { B } & \text { DR } \\ \text { b } & 2 & 35 & 4 \\ \text { e } & 32 & 40 & \text { b } \\ \text { i } & 25 & 18 & 2 \\ \text { k } & 10 & 18 & - \\ \text { k } & 2 & 40 & -\end{array}$

FIG 7 Family 7.

Family 2 contains a brother (I.1) with RA and a sister (I.3) with Graves' disease who are HLA identical and share one $\mathrm{Gm}$ haplotype.

Family 3 is informative for HLA only. The proband with RA (I.2) and his sister with thyrotoxicosis (I.3) share a DR5 bearing HLA haplotype. I.3 shares no HLA haplotypes with the other sib (I.4) who has RA.

In family 4 the proband (II.2) and sister with hypothyroidism (II.1) share both HLA haplotypes and one Gm haplotype. The other sister with RA

TABLE 2 HLA haplotype sharing by sib pairs with (1) $R A$ and autoimmune thyroid disease (TH);

(2) $R A$ and thyroid autoantibodies (th); (3) DR4 positive $R A$ and $T H$ or th sibs; (4) DR4 negative $R A$ and $T H$ or th sibs.

\begin{tabular}{lrrrr}
\hline Haplotypes shared & & 0 & 1 & 2 \\
\hline (1) RA-TH & $(10)$ & 3 & 4 & 3 \\
(2) RA-th & $(16)$ & 5 & 7 & 4 \\
(3) DR4 positive RA-th/TH & $(9)$ & 3 & 4 & 2 \\
(4) DR4 negative RA-th/TH & $(17)$ & 5 & 7 & 5 \\
Total & $(26)$ & 8 & 11 & 7 \\
\hline
\end{tabular}

TABLE 3 Gm haplotype sharing by sib pairs with $R A$ and (1) autoimmune thyroid disease (TH); (2) thyroid autoantibodies (th).

\begin{tabular}{lrlll}
\hline Haplotypes shared & & 0 & 1 & 2 \\
\hline (1) RA-TH & $(7)$ & 1 & 4 & 2 \\
(2) RA-th & $(4)$ & 1 & 3 & 0 \\
Total & $(11)$ & 2 & 7 & 2 \\
\hline
\end{tabular}

(II.3) is identical to the proband with respect to $\mathrm{Gm}$ and shares one HLA haplotype.

Family 5 shows sharing of both $\mathrm{Gm}$ haplotypes by all three sibs with either thyroid disease (Graves' disease) or RA (I.1, I.2, I.3). The elder sister with Graves' disease shares one HLA haplotype with the proband but has no haplotypes in common with her other brother with RA.

In family 6 the brother with RA (II.2) and sister with Graves' disease (II.1) share one HLA and one Gm haplotype.

In family 7 there is sharing of both HLA haplotypes between the brother with RA (I.3) and the sister with hypothyroidism (I.4). This family is not informative for $\mathrm{Gm}$ haplotype sharing.

HLA AND GM HAPLOTYPE SHARING

The results of HLA haplotype sharing by 10 sib pairs with RA or ATD alone and 16 sib pairs with RA or thyroid autoantibodies are summarised in table 2 . The distribution of HLA haplotype sharing is random (by chance we would expect six or seven of the $26 \mathrm{sib}$ pairs overall to have no haplotypes in common). The frequencies of HLA haplotype sharing by sib pairs with autoimmune thyroid disease and either DR4 positive or DR4 negative RA are similar.

The distribution of $\mathrm{Gm}$ haplotype sharing in the smaller number of informative sib pairs is also random (table 3).

\section{Discussion}

If a single, relatively uncommon, dominant, susceptibility gene, linked to either HLA or Gm, predisposed to both RA and ATD, we would expect 
greater than random sharing of HLA or Gm haplotypes by appropriate sib pairs. ${ }^{13}$ No such trend is seen for either marker, suggesting that although the numbers are small this simple model for a single HLA or Gm linked gene predisposing to both RA and ATD is incorrect. Our approach may be criticised firstly for the treatment of different types of ATD as genetically homogeneous, and it might be that different results would be obtained if sufficient numbers of each type of thyroid disorder were considered alone. (There is no trend from the present studies to support this.) Our analysis, which groups the different types of ATD together, is also supported by the following.

(1) Different clinical forms of ATD frequently occur in the same family suggesting that they may have autoimmune disease genes in common.

(2) Others have previously demonstrated ${ }^{14}$ in family studies that different clinical forms of ATD may have HLA and Gm linked genes in common, despite their different HLA and Gm associations in unrelated patients.

(3) Present concepts of ATD pathogenesis suggest the presence of a broad spectrum of immunological disease processes with overlap of autoantibodies produced in differing clinical disease states. ${ }^{15}$

Secondly, RA itself appears genetically heterogeneous and previous results of HLA haplotype sharing by RA sibs suggest that there are at least two independent RA susceptibility genes, one in linkage disequilibrium with HLA-DR4, and one independent of DR4 which appears to predispose to both RA and to ATD (Grennan et al, unpublished data). It is of interest, therefore, to examine HLA and Gm haplotype sharing by sib pairs with DR4 negative RA and clinical or immunological evidence of ATD, respectively. HLA and Gm haplotype sharing by these sib pairs is no greater than when pairs including a DR4 positive RA sib are considered. Thirdly, a common environmental aetiology is a further possibility to explain our findings but seems unlikely, particularly as ATD is found in increased frequency in first and second degree relatives of RA probands. ${ }^{1}$

It seems likely, therefore, that genes linked to neither HLA nor Gm loci contribute to the common predisposition to RA and ATD. Others have also failed to find evidence for susceptibility genes linked to either HLA or Gm, which might predispose to autoimmune disorders including ATD in the families of patients with Sjögren's syndrome. ${ }^{16}$ The genetic predisposition to RA, ATD, and other autoimmune diseases seems likely to include a complex interaction between HLA linked and Gm linked genes, as well as non-HLA, non-Gm linked genes which have yet to be localised. An interaction between at least three genes in the pathogenesis of RA could be predicted from consideration of the concordance figures for disease in monozygotic and dizygotic twins. ${ }^{17}$ The $\mathrm{Km} 1$ allotype which is coded for by genes on chromosome 2 is associated with altered immunological response to bacterial polysaccharides, ${ }^{18}$ and an association has been described between RA and a genetic variant of complement $\mathrm{C} 3$ coded for by genes on chromosome 19. ${ }^{19}$ Markers on both these chromosomes would be worth examining in future studies of autoimmune disorders including RA and ATD.

These studies were partially funded by research grants from the North West Regional Health Authority and the Arthritis and Rheumatism Council (ARC). We are grateful to P H Van Eede, A M Van Leeuwen, and Irene Smeaton for technical assistance.

\section{References}

1 Thomas DJB, Young A, Gorsuch AN, Bottazzo GF, Cudworth AG. Evidence for an association between rheumatoid arthritis and autoimmune endocrine disease. Ann Rheum Dis 1983; 42:297-300.

2 Stastny P. Rheumatoid arthritis. In: Terasaki P, ed. Histocompatibility testing. Los Angeles: UCLA Press, 1980:681-6.

${ }^{3}$ Farid NR, Simpson L, Noel P, et al. A study of human leukocyte D locus related antigens in Graves' disease. $J$ Clin Invest 1979;63:108-13.

4 Weissel M, Hofer R, Zasmeta H, Mayr WR. HLA-DR and Hashimoto's thyroiditis. Tissue Antigens 1980;16:256-7.

${ }^{5}$ Cox DW, Markovic VD, Teshima IE. Gene for immunoglobulin heavy chains and for $\alpha_{1}$-antitrypsin are localised to specific regions of chromosome 14q. Nature 1982;297:428-30.

6 Propert DN, Kay P, McCluskey J, Zilko PJ, Mathews J. Immunoglobulin allotypes in rheumatoid arthritis. In: Dawkins $\mathrm{RL}$, Christiansen FT, Zilko PJ, eds. Immunogenetics in rheumatology. Musculoskeletal disease and D-penicillamine. Amsterdam: Excerpta Medica, 1983:127-9.

7 Sanders PA, DeLange GG, Dyer PA, Grennan DM. Gm and $\mathrm{Km}$ allotypes in rheumatoid arthritis. Ann Rheum Dis 1985;44: 529-32.

${ }^{8}$ Farid NR, Newton RM, Noel ED, Marshall WH. Gm phenotypes in autoimmune thyroid disease. $J$ Immunogenet 1977;4: 429-32.

9 Grennan DM, Dyer P, Dodds W, et al. Clinical and immunogenetic studies in multicase rheumatoid families. $Q \mathrm{~J} \mathrm{Med}$ 1984;53:479-85.

10 Ropes MW, Bennett GA, Cobb C, et al. Diagnostic criteria for rheumatoid arthritis, 1958 revision. Ann Rheum Dis 1959;18: 49-53.

1 Van Loghem E. Genetic studies on human immunoglobulins. In: Weiss DM, ed. Handbook of experimental immunology. 3rd ed, chap 11. Oxford: Blackwell, 1978:11.1-11.16.

12 Walton K, Dyer PA, Grennan DM, Haeney M, Harris R. Clinical features, autoantibodies and HLA-DR antigens in rheumatoid arthritis. $J$ Rheumatol 1985;12:223-6.

${ }^{13}$ Thomson G, Bodmer W. The genetic analysis of HLA and disease associations. In: Dausset J, Svejgaard $\mathrm{A}$, eds. $H L A$ and Disease. Copenhagen: Munksgaard, 1977:84-93.

${ }^{14}$ Tamai $\mathrm{H}$, Uno $\mathrm{H}$, Hirota $\mathrm{Y}$, et al. Immunogenetics of Hashimoto's and Graves' diseases. J Clin Endocrinol Metab 1985;60:62-6. 
15 Editorial. Thyroid autoimmune disease: a broad spectrum. Lancet 1981;i:874-5.

16 Reveille JD, Wilson RW, Provost TT, Bias WB, Arnett FC. Primary Sjögren's syndrome and other autoimmune disease in families. Ann Intern Med 1984;101:748-56.

17 Lawrence JS. Rheumatism in populations. London: Heinemann, 1977:240-2.

18 Pandey JP, Virella G, Loadholt CB, et al. Association between immunoglobulin allotypes and immune response to haemophilus influenzae and meningococcal polysaccharides. Lancet 1979;i: 190-2.

${ }^{19}$ Farhud DD, Ananthakrishnan R, Walter H. Association between C3 phenotypes and various diseases. Humangenetik 1972:17:57-60.

Correspondence and request for reprints to Dr D M Grennan, Rheumatic Diseases Centre, Hope Hospital, Salford M6 8HD. 